\title{
Measures and Possible Support Solutions of the Sustainable European Economy in the Context of Actual Crises
}

\section{Otilia Manta}

PhD, Romanian Academy, Center for Financial and Monetary Research "Victor Slăvescu”, Romanian-American University

\section{Abstract}

The COVID-19 pandemic involves the major risk of a severe recession, and of the economic, financial, social, educational crises, which will affect the entire EU economy, with consequences for citizens, businesses, jobs, and households. In order to guarantee the continued availability of sufficient liquidity on the market, to counteract the damage caused to healthy enterprises and to maintain the continuity of economic activity during the epidemic and after the end of the COVID-19 pandemic, it is necessary to develop a plan of measures and solutions. supporting the European economy, both through direct measures of state aid, as well as through measures to support/develop/innovate the business environment through the EU funding programs allocated at the level of the Member States both in the period 20142020, but more elected 2021-2027, the effects of the current crisis being both short term, but especially in the medium and long term. Among the objectives pursued we propose: identification and proposal of state aid measures to support the economy in the context of the current epidemic of COVID-19 through close coordination at European level of the aid measures; estimating the impact of temporary state aid measures on the European economy through the intervention of the European Commission; and ways to attract European funds for the business environment through the European Union funding programs existing in the budget for the period 2014-2020, but especially for the period 2021-2027.

Keywords: economic crisis, European economy, sustainable development

\section{Introduction}

The current challenges at the European level (including global) and its financial and economic consequences have caused a major economic slowdown, especially on small businesses, and the European Union in the period February-April 2020 has concretely supported through monetary and fiscal policy, respectively through (European Commission, 2020):

The temporary framework of the European Commission; 
Fiscal policy instruments and Multiannual Financial Framework 2014-2020;

Multiannual Financial Framework 2021-2027;

European Investment Plan for European Green Transactions.

The State aid financial instrument could also be used during this period to remedy the serious disturbances of the economy. According to official European Commission documents, the Temporary Framework adopted in March 2020 established temporary state aid measures that the Commission will consider compatible with state aid rules, thus allowing Member States full flexibility in supporting coronavirusaffected economies. The temporary framework was created to respond more effectively to the different needs of the Member States. Moreover, it initially focused on measures to ensure liquidity in the economies of the Member States. In early April this year, it was extended to include measures to support the medical economy and investment, coronavirus-related research and production, measures to relax the social and tax obligations of companies and the self-employed, and measures to subsidize employee salaries, including of micro-enterprises.

Experts argue that the Temporary Framework includes emergency liquidity measures for the business environment, as well as temporary tax deferrals for businesses, which are considered to be the most effective policy measures (Boumans, D., 2020). Moreover, it is considered that financial support must be carefully dimensioned for each economic agent, so as to avoid both the economic crisis and the financial crisis.

\section{Methodology of scientific research}

The methods and tools that formed the basis of this paper are the classical ones, respectively instruments of observation and examination, research methods based on the basic principles of scientific research. Moreover, we performed procedures based on factual analysis, as a result of significant practical work experience and intense documentation at the level of existing literature, especially at European level, but we correlated with the information identified internally and internationally in the context of these global challenges generated by the pandemic COVID 19.

\section{Research results}

At the level of the Member States of the European Union, policy measures (fiscal, sectoral, regional, economic, and others) have been taken against the spread and impact of COVID-19 through the Temporary Framework of the European Commission. All these measures have been reported at the level of the European Commission by each Member State, the policy measures being of direct (potential) relevance for economic and fiscal surveillance. This includes measures on expenditure (eg higher health care expenditure, short-term employment benefits) or revenue (eg tax deferrals) of the budget, measures specific to certain sectors of the economy or regions, and measures to support lending to national economies (eg public guarantees, bank support measures, policy decisions of the national central bank). 
Many Member States have also taken precautionary measures in the form of general guidelines for citizens, travel bans, school/university closure, the adoption of telework measures, etc., with macroeconomic and budgetary implications. In order to have a comprehensive overview of the measures announced or taken so far in the Member States, we will present in the paper the measures for each Member State.

The quantification of these measures and their expected impact on the government deficit and debt figures can be estimated, but the effects and impact of these measures could be analyzed in the next half of the year.

The impact of temporary state aid measures on the national economy through the intervention of the state and the European Commission

The new Temporary Framework for State aid in the context of the COVID-19 crisis (19 March 2020) was a direct form of support for the Member States, allowing them to provide direct subsidies of EUR 500,000 per company, state guarantees for loans and subsidized interest rates to mitigate the effects of COVID-19. In the context of the current EU state aid rules, Member States are required to notify the European Commission of the aid scheme they want to implement and obtain approval before actually implementing it. At the same time, it should be noted that there are exceptions to this general prohibition which allow certain types of aid to be granted in certain special circumstances, without prior notice.

Exceptions to the obligation to notify State aid schemes include the exception whereby State aid "supports the remedying of economic damage caused by natural disasters or exceptional occurrences". This exception allows, for example, the compensation of airlines for losses suffered due to the COVID-19 crisis.

The temporary framework related to the COVID-19 crisis was designed to directly support the real economy at the level of each Member State and indirectly through certain financial instruments, the banking sector (Dorn et al. 2020). However, as can be seen from the analysis per Member State in the new Temporary Framework shows that aid to banks to maintain the flow of credit to companies will also be considered as indirect aid to companies (since they will be aimed at combating illiquidity and supporting a harmonized fiscal response at EU level), some of which fall into the category of Expenditure Measures taken at the national level. Moreover, the new Temporary Framework allows the following types of aid, intended for companies that have suffered financial losses after December 31, 2019 (European Commission, 2020):

1. Direct granting of financial support or tax advantage - Member States have the possibility to set up aid schemes of up to EUR 500,000 to individual companies to meet urgent liquidity needs. This aid may be provided in direct form or as a tax advantage;

2. State guarantee of bank loans, direct support on the real economy and indirect financial-banking sector - Member States will be able to guarantee bank loans to companies or create a scheme for both investment and working capital. These 
schemes would be subsidized as a matter of priority, but the Commission may impose a maximum loan amount depending on the real liquidity needs of the companies. This category also includes the Package of measures adopted by the Government of Romania on March 18 a.c. and which also provides for an intervention fund of 10 billion lei to provide guarantees to SMEs for contracting loans to finance investments and working capital. The Ministry of Finance will guarantee $80 \%$ of the loans for SMEs, $90 \%$ of the loans for micro-enterprises, and will subsidize $100 \%$ of the interest associated with the guaranteed loans. On March 19, the authorities said that the Fund could be increased by an additional 5 billion lei, if necessary. An approximate estimate of the fiscal cost (subsidized interest): RON 250 million.

3. Subsidized interest rates for loans secured by State guarantees - Member States will be allowed to grant loans (for investments) using subsidized interest. The interest rate must be at least equal to the amount of the base rate set on 1 January 2020; the credit risk premium corresponding to the recipient. Different rates can be set for SMEs and non-SMEs. The intention is to use a fixed base rate to provide certainty to the business environment in the Member States. As in the field of State guarantees, the Commission may impose a maximum loan amount based on the actual liquidity need of the beneficiary in order to prevent distortions of competition in the market and to obtain unfair advantages.

4. Direct state aid to the banking sector - Member States will be able to help banks and financial companies directly, which will also be considered as an aid to the real economy.

The temporary framework provides guidance and clarifies how the Member States should maximize the amount of aid granted to firms or agencies involved in the real economy directly or indirectly in the form of a larger volume of financing, risk portfolio aid, aid for higher guarantee requirements. for lower guarantee premiums or lower interest rates (S. López Piqueres, 2020). Moreover, in order to strike a balance at the European level, aid caps are introduced, as well as to limit undue support or residual financing for the banking sector.

5. State aid schemes in the form of direct loans, repayable advances or tax exemptions - these State aids could also be granted based on Article 107 (3) TFEU, in the form of temporary amounts, limited to a certain ceiling, but, under the current Temporary Framework, they can also be granted to enterprises and small companies in financial difficulty (lack of liquidity), if the Member State concerned considers that such measures are appropriate and necessary in the current exceptional circumstances induced by the COVID-19 crisis. As a result, the European Commission will consider such aid to be compatible with the provisions of the internal market and Article 107 (3) TFEU provided that simultaneous eligibility criteria are met: State aid does not exceed EUR 800,000, gross (ie before the application of tax exemptions or other tax burdens) per company; the aid is granted in the form of a scheme with an estimated budget; aid can also be granted to enterprises that were not in "difficulty" on 31 
December 2019, but are currently in "difficulty" due to the negative effects of the COVID-19 crisis; the aid is granted until 31 December 2020.

Regarding the aid granted to companies that process or distribute agricultural and food products, there are, in the Temporary Framework, some special provisions. Thus, the aid granted to these companies is conditional on them not being part (in whole or part) of the primary production process and is not capped based on the price or quantities purchased by these traders from the primary producers. For the agriculture, fisheries and aquaculture sectors, it is specified that aid granted under the current Temporary Framework may be cumulated with de minimis aid, but not exceeding EUR 100,000 per undertaking.

To a large extent, all these support measures provided for in the Temporary Framework of the European Commission are found in the state aid schemes intended to support the real economy and have been adopted by our authorities.

\section{Ways to attract European funds for the business environment through European Union funding programs}

The analysis of the measures taken by each Member State shows that very few states have resorted to the financing measures provided for in the Multiannual Financial Framework 2014-2020, among which we mention Bulgaria, Latvia, and Romania. Measures were taken by the Romanian authorities regarding the allocation of financial resources from European funds, respectively from the European Union Programs 2014-2020, namely: the use of an additional 350 million euros from EU funds for the purchase of Covid-19 tests, protective equipment and mechanical ventilation equipment (March 24); The Ministry of European Funds announced on 25 March an additional allocation of EUR 682 million from EU funds to the Inspectorate General for Emergency Situations for the purchase of medical and emergency equipment; The EU funds minister said on March 18 that the government would use EUR 300 million. EU funds allocate funding to support measures for people who lose their jobs due to the COVID-19 crisis. The money will be attracted from allocations to the Human Resources Operational Program. The Minister of Regional Development said he would launch a line of funding to provide up to $€ 1$ billion in aid to SMEs and EU funds. The measure is temporary and if the expected amounts are not enough, other sources of EU funding will be sought.

\section{European investment plan for European green transactions - considerations}

The European Green Deal is the European Union's (EU) new growth strategy to promote the transition to a climate-neutral economy by 2050. Confirming the importance of financial resources for such an objective majority, its investment pillar was the first initiative of the presented strategy. The European Investment Plan for Green Transactions, also known as the Sustainable Europe Investment Plan, aims to help finance a sustainable transition while supporting the regions and communities most affected by its impact. According to official documents issued by the European 
Commission and the European Parliament, by combining legislative and nonlegislative initiatives, the plan addresses three issues:

1) mobilizing funding of at least $€ 1$ trillion from the EU budget and other public and private sources over the next decade;

2) putting sustainability at the heart of investment decisions in all sectors;

3) providing support to public administrations and project promoters to create a solid pipeline of sustainable projects.

The EU's Multiannual Financial Framework (2021-2027) has traditionally been a strong supporter of climate and environmental goals, with resources commensurate with the goal of facilitating a smooth transition to a carbon-neutral economy. The impact of the pandemic has raised concerns that decarbonization strategies could be derailed. However, more than ever, experts and stakeholders generally agree with their continued relevance, arguing that green investment from public and private sources must play a central role in any economic recovery plan at European level, and implicitly in local level.

The European Union (EU), is a supporter and leader in the fight against climate change at international level, is expected to further intensify its actions in this field during its institutional cycle 2019-2024. On 11 December 2019, in her first weeks in office, European Commission President Ursula Von der Leyen launched the European Green Deal as a new EU growth strategy to promote and facilitate the transition to a green, competitive and inclusive economy. Such a major economic transition requires huge financial investments, including to ensure that the process benefits all parts of society and to support the citizens and regions most exposed to the costs of decarbonisation (R. Waldholz, 2020).

Based on the current target of reducing greenhouse gas (GHG) emissions by $40 \%$ by 2030 compared to 1990 levels, the European Commission has estimated that additional investments of $€ 260$ billion per year will be needed. year to meet this target. Given that the environmental agreement intends to increase the intermediate target of reducing GHG emissions by at least $50 \%$ by 2030 , the resulting financial needs will be even greater. For this reason, a measure planned under the Green Agreement is an investment plan to mobilize public and private funding towards the objectives of a fair transition to a green economy.

On 14 January 2020, the European Commission published a communication detailing the European Investment Plan for Green Transactions, also known as the Investment Plan for Sustainable Europe. The investment plan, which complements other initiatives expected under the European Green Agreement, aims to provide and use the necessary funding for the transition to 2030, seeking to put sustainability at the heart of both public and private sector investment and spending. the private one. In the period 2021-2030, the European Commission will mobilize at least $€ 1$ trillion in sustainable investment by increasing resources for climate action within the EU budget and by using additional public and private funding. Part of the global resources 
will be specifically designed to support the regions most exposed to the challenges of the transition.

The mobilization of financial resources worth 1 trillion euros over ten years is part of the investment plan that has so far attracted the attention of the majority. According to official documents, about half of the amount would come directly from the EU budget, while other public and private sources would provide the rest, mainly through leverage. Furthermore, we believe that the European Investment Bank (EIB) should be a key partner in mobilizing additional funding, as it is expected to trigger investments of up to around $€ 250$ billion (ie a quarter of the total) according to EU mandates under the investment plan. Given that the EIB has announced its own target of supporting $€ 1$ trillion in climate action and investment in environmental sustainability over the next decade, it should be noted that the two targets only partially overlap. Therefore, it can be deduced that taken together, the European Investment Plan for Green Transactions and the EIB target should have the potential to provide around $€ 1.75$ trillion in climate-related finance.

The overall level of investment for the European Investment Plan for Green Transactions requires further clarification on its time horizon, which covers the decade 2021-2030, in line with the fact that the current EU climate targets are for 2030. the next Multiannual Financial Framework (MFF) 2021-2027 is intended to cover a period of seven years, from 2021 to 2027. The European Commission has therefore calculated the total amount on the assumption that the next MFF, scheduled to start in 2028, will maintain at least the same level of ambition as its predecessor for climate finance for the last three years of the decade.

\section{Figure 1 - Financing elements making up at least $€ 1$ trillion over the 2021-2030 period under the European Green Deal Investment Plan}

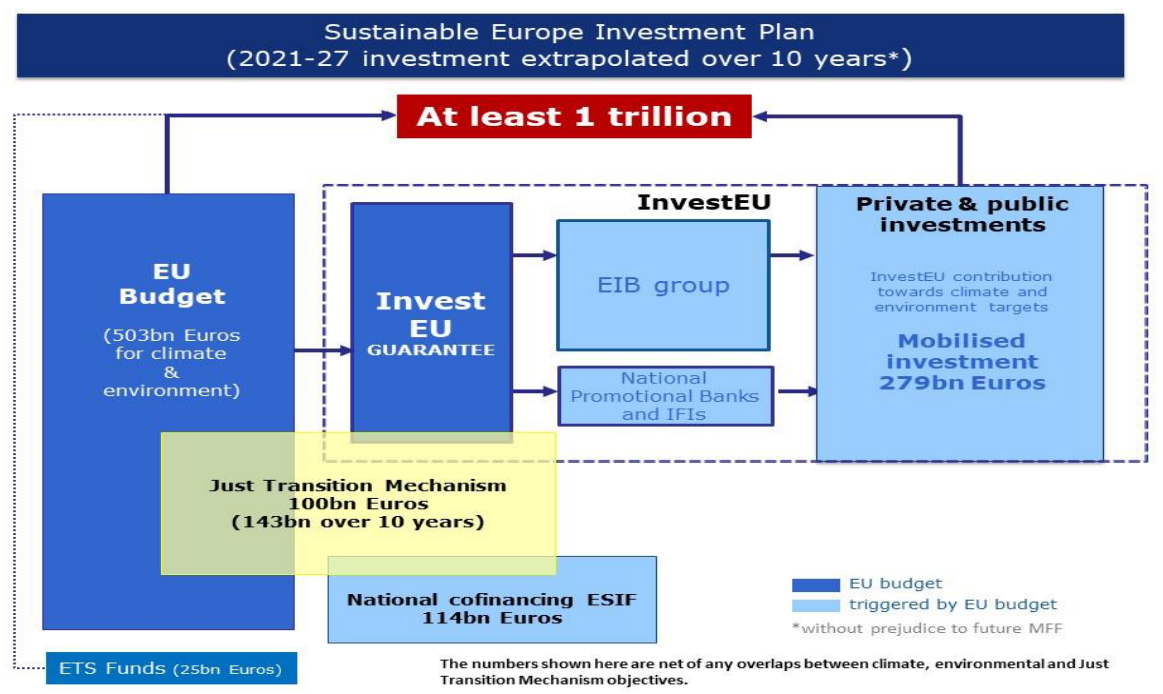

Source: European Commission., 2020 
The above figure shows the details of the total figure component of at least EUR 1 trillion. Furthermore, the European Commission presents this figure as clear from possible overlaps, taking into account the fact that different sources of funding and/or instruments may interact and contribute to a particular joint project or operation. In descending order of magnitude, five broad categories of climate finance sources would support a wide range of projects and contribute to the European Investment Plan for Green Transactions, as follows:

1. EU budget totaling EUR 503 billion. The European Commission has proposed that at least $25 \%$ of post-2020 MFF resources be allocated to climate-related spending, by incorporating climate considerations into numerous EU budget funds and programs. Tools that should make a significant contribution to this goal include:

a. funds under the common agricultural policy (CAP);

b. European Regional Development Fund (ERDF);

c. Cohesion Fund 2021-2027;

d. Horizon Europe Framework Program for Research and Innovation;

e. LIFE program; and

f. Connecting Europe Facility (CEF).

This approach is based on the experience with climate integration in the current MFF, below which the climate target amounts to 20\% of total resources 2014-2020.

2. The EIB Group and other investment partners in the context of InvestEU (EUR 279 billion). The proposal for the MFF 2021-2027 includes the creation of the InvestEU program to streamline in a single investment scheme the operations currently carried out under the European Fund for Strategic Investments (EFSI) and various financial instruments supported by the EU budget. Moreover, InvestEU would be the key tool to exploit the capacity of the EU budget to benefit from additional public and private funding for investments in the Union's internal policies, as well as its targeting of the dominant segment of business beneficiaries, namely SMEs. The Commission has proposed a 30\% climate target for InvestEU operations. The Commission intends to develop financial products aimed at ecological, climate, and social sustainability within InvestEU. The Multiannual Financial Framework (MFF) has a focus on the regions and communities most exposed to the transition challenges, this mechanism would be structured on three pillars (see figure below): 


\section{Figure 2 - Just Transition Mechanism over the period 2021-2027}

Just Transition Fund

to generate financing of

$€ 30-50$ billion

- New Just Transition Fund of $€ 7.5$ billion

- Transfers: for each $€ 1$ from JTF $€ 1.5-3$

from ERDF/ESF+

- National co-financing

Provides primarily grants
Just Transition Mechanism

at least EUR 100 billion investments

to support and finance regions most exposed

to transition challenges in all Member States

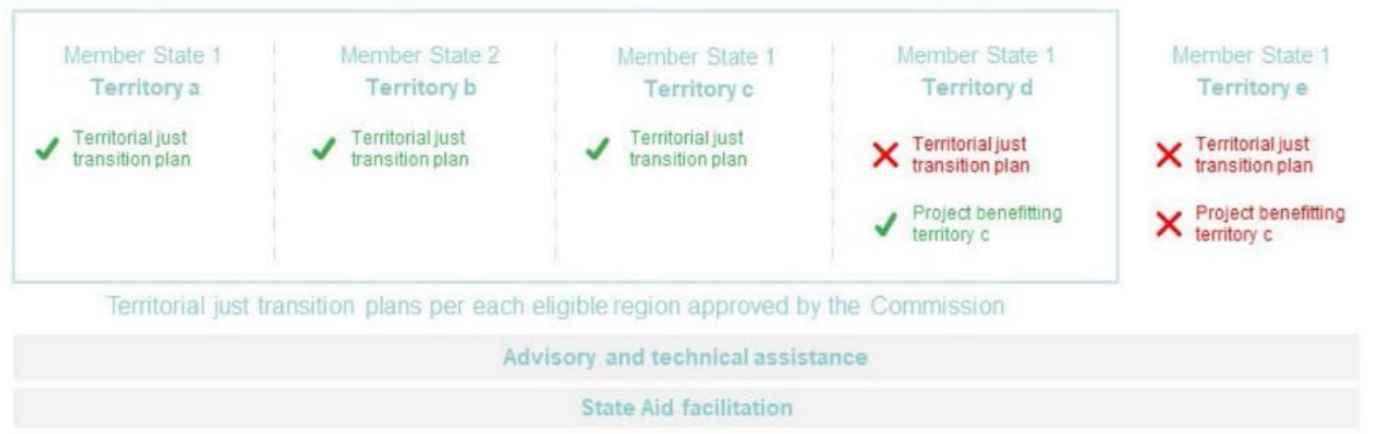

Source: European Commission, 2020

Just Transition Mechanism, with the following:

a. a fair transition fund, with $€ 7.5$ billion in new money by 2027 and a specialized fair transition scheme within InvestEU;

b. as well as a new public sector loan facility, with the EIB, to benefit from additional public funding.

Particular attention is paid to economic sectors that provide additional jobs, namely in the sector of activity the production of fossil fuels or related industries. Under cohesion policy, EU Member States will identify eligible regions and the envisaged transition process by 2030 , in the fair territorial transition plans to be approved by the European Commission. Member States and regions will receive technical and advisory support from the Commission through a fair transition platform. 


\section{Discussion}

The paper is an empirical research based on official documents reported by European Union member states in the early days of the COVID pandemic. Moreover, this period coincides with the new financial programming period at European level, as well as with the launch of new strategic programs until 2030 and 2050, respectively.

As regards the general financial system, the EU taxonomy will play a major role in the measures designed to put sustainable finance at its center. The Commission will also explore how the EU taxonomy, originally designed for the private sector, could be used by the public sector beyond the scope of InvestEU to promote synergies. Besides, a renewed strategy for sustainable financing is envisaged, including the creation of a European Green Bond Standard as a tool for increasing public and private finance for sustainable investment.

Also, the Commission will develop a "Sustainable Procurement Screening" tool to provide tailored support to public investors in implementing their projects.

In May 2018, the European Commission presented its proposal for the new MFF which should cover the period 2021-2027, calling for an agreement to be reached before the 2019 European elections to avoid delays in the implementation of related instruments. Among other things, the Commission has proposed raising the climate integration target from $20 \%$ of total resources to $25 \%$.

In the context of the European Green Agreement, climate integration in the EU budget should be further intensified, proportionate resources to facilitate a fair transition to a carbon-neutral economy. The call for further change towards climate transition included the call for a new and strengthened methodology for climate integration, with strong performance indicators and provisions to prevent any financial support for climate-damaging measures.

The emergence of Covid-19 and the declaration of a pandemic by the World Health Organization (WHO) in March 2020, caused significant uncertainty, triggering the announcement of packages of economic incentives to mitigate the social and economic impact of the public health crisis. An article published by the Peterson Institute for International Economics (PIIE) highlights the central role that public and private investment under the European Green Agreement must play in any recovery strategy. Drawing attention to the falling price of oil, the author recommends that the EU and its Member States keep fossil fuel prices for consumers at pre-crisis levels, through higher taxes, as a crucial measure for their decarbonisation efforts.

The goal would be twofold: on the one hand, the public sector would have additional revenue to combat the pandemic and its consequences; on the other hand, the move would prevent the price of oil from falling. However, the Commission said it would continue its intensive work on climate issues. As previously planned, the Commission has launched a public consultation on the upward revision of the GHG reduction 
target for 2030, which aims to gradually increase the road to climate neutrality in 2050. Furthermore, the European Environment Agency (EEA) intends to assess the impact of the pandemic on production and consumption patterns once the crisis passes. The Multiannual Financial Framework 2021-2027 is directly linked to the attitude of Member States to be directly involved in the adoption of measures, so that from 2021, small and medium-sized enterprises can use the financing instruments so necessary for their sustainability.

In May 2020, European Commission President Ursula von der Leyen presented the Commission's proposal for an economic recovery plan following the $€ 750$ billion coronavirus pandemic Next Generation EU, and according to the official communiqué, it includes the following :

The proposed recovery instrument, Next Generation EU, will have a budget of $€ 750$ billion, which will be in addition to the long-term budget, according to President von der Leyen.

The money for the Next Generation EU will be raised by temporarily raising the own resources ceiling to $2 \%$ of the EU's Gross National Income. This will allow the Commission to use its very strong credit rating to borrow $€ 750$ billion in EU financial markets for the next generation.

According to the official document published today by the European Commission on the proposed solutions, in addition to the Next Generation EU, a renewed EU budget is proposed, amounting to approximately 1.1 trillion euros in the period 2021-2027.

All money raised through the Next Generation EU and the new EU budget will be channeled through EU programs.

Next Generation EU money will be invested in three pillars, with $€ 500$ billion in grants and $€ 250$ billion in loans to the Member States.

The first pillar is support for the Member States for investment and crisis resolution reforms:

- A new Recovery and Resilience Facility with a budget of EUR 560 billion - distributed in grants and loans. It will support the Member States in implementing investments and reforms that are essential for a sustainable recovery. Member States will design their own national recovery plans, based on investment and reform priorities identified as part of the European Semester, in line with national climate and energy plans, fair transition plans and partnership agreements, and operational programs from EU funds.

- A new initiative, REACT-EU, will provide a supplement to cohesion support to the Member States with a budget of $€ 55$ billion. It will be available from 2020 and will be distributed according to a new allocation key, taking into account the impact of the crisis. This will ensure that there is no interruption in funding for key crisis relief measures and the support of the most disadvantaged. It will support workers and 
SMEs, health systems, and green and digital transitions and will be available in sectors - from tourism to culture.

- To support the green transition, the Commission aims to provide additional funding for the Fair Transition Fund and the European Rural Development Fund. Cohesion policy programs will also be strengthened in the next EU budget period, to also allow for greater flexibility.

The second pillar is to launch the EU economy by stimulating private investment:

- A new Solvency Support Instrument will mobilize private resources to provide urgent support to healthy companies. Investments will be channeled to companies in the most affected sectors, regions, and countries. This will help balance the "game" conditions for those Member States that are less able to support through state aid. It can be operational from 2020 and will have a budget of 31 billion euros, which aims to unlock more than 300 billion euros in support of solvency. Guidelines will be developed to help align investment with EU priorities.

- The Commission aims to modernize InvestEU, the EU's main investment program, by doubling its capacity.

- In addition to the above, a Strategic Investment Facility will be created within InvestEU. It will be able to unlock investments of 150 billion euros thanks to the 15 billion euros brought to it by Next Generation EU. This will invest in strengthening our resilience and strategic autonomy for key technologies and value chains.

The third pillar is about learning lessons about the crisis:

The Commission intends to set up a new autonomous EU4 Health program with a budget of EUR 9.4 billion. It will invest in prevention, crisis preparedness, the purchase of vital medicines and equipment, as well as in improving long-term health outcomes. A number of other key programs will be strengthened to learn the lessons of the crisis, in particular rescEU and Horizon Europe.

In addition to the three pillars, the Commission aims to strengthen a number of other programs in the EU budget, compared to those discussed by the European Council in February. These include: Common agricultural policy; European Maritime and Fisheries Fund; The Single Market Program and programs that support tax and customs cooperation; Connecting Europe Facility; Erasmus +; Creative Europe Program; Digital Europe Program; European Defense Fund; Internal Security Fund; Asylum and Migration Fund, and Integrated Border Management and Pre-Accession Assistance Fund.

For the proper management of funding instruments through the programs, we believe that there should be a correlation and integration from and between the priorities of citizens and the business environment, respectively according to the figure below: 
Figure no. 3. Direct relationship to and from the Programs, Priority Directions and Projects of Citizens and the Business Environment in Europe

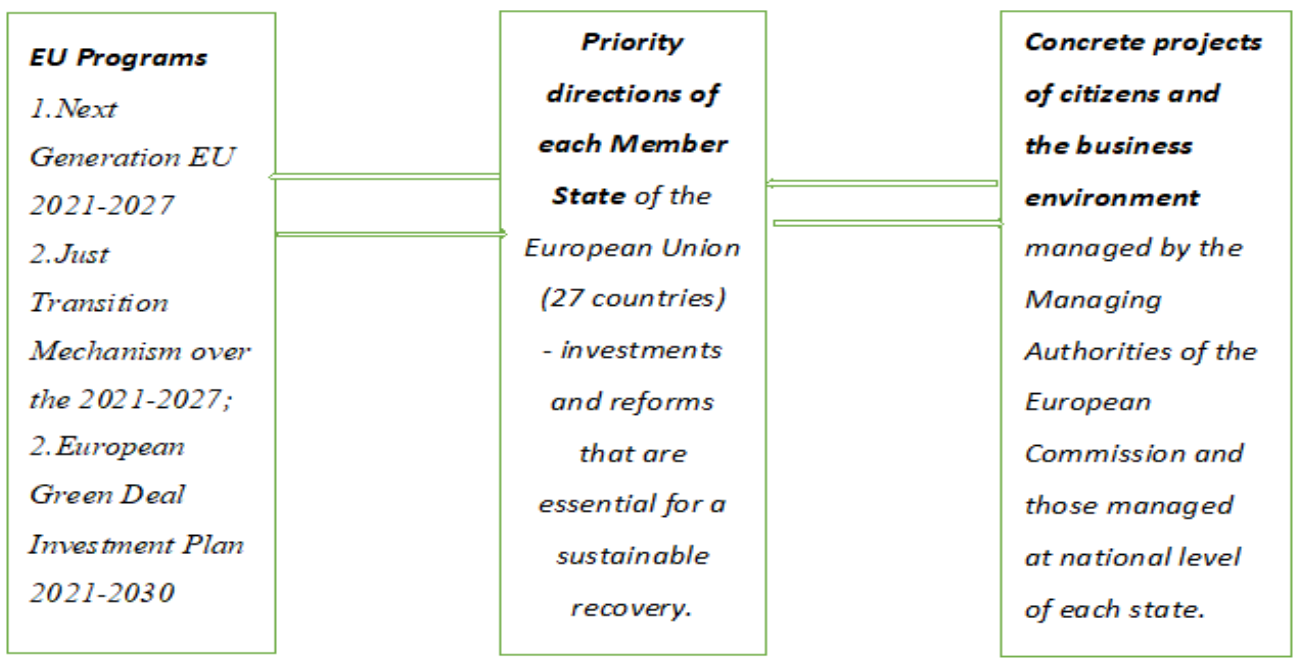

Direct and permanent interconnection relations from and to the Programs, Priority Directions of each Member State of the European Union (27 states) and Concrete Project of citizens and business environment managed by the Managing Authorities of the European Commission and those managed at national level of each We believe that it is the solution to the management and orientation of funding sources towards European priorities in the context of current challenges at European and global level.

\section{Conclusion}

The reduction of the impact of the COVID-19 crisis required a rapid, focused and coordinated response from all states in the field of state aid (as shown by the analysis of each Member State), as well as to support the most vulnerable economic agents ( including companies in the public catering sector, services, etc.).

State support is required to be: aimed at reducing the disruptive economic effects of the epidemic, and clearly defined and limited to what is needed to address the acute economic crisis, excluding unjustified benefits for companies or the banking sector, to be borne by taxpayers in EU Member States.

In order to turn state aid into an effective tool for supporting the real economy across the EU, sufficient behavioral rules are needed for beneficiaries to prevent the abuse of state support, such as, for example, company expansion or aggressive market strategies. with the help of a state guarantee (Manta, 0., 2017).

At present, in addition to their own efforts, it is necessary to exogenously finance the business of companies. For European companies, even in conditions of economic 
crisis, exogenous financing through bank loans is the main solution to cover the need for financing both the current activity and their own development projects;

In the period 2020-2030, companies will have the improvement of financing through government intervention, but especially through innovative financial instruments that are in line with the principles of green financing and are found in the Multiannual Financial Framework 2021-2027.

Measures taken by other countries and which can be taken at the level of any state: setting up a government and business unit COVID 19 (following the example of the Danish Government) in collaboration with relevant business organizations and labor market organizations to solve sectoral economic problems. Among the main objectives should be MicroFinance Fund with a potential loan threshold of $€ 50,000$ and intended to finance small family businesses; support for programs for SMEs (packages of financial instruments, ie loans, and guarantees to support current activities and development of investment and technology plans in accordance with green investment support policies); launching state-subsidized leisure vouchers to help hotels recover from the crisis; tourism support (EUR 11 million). Additional budget for the implementation of actions to support tourism in June-September 2020, in cooperation with airlines and tourism organizers, as well as actions to improve initiatives to attract tourists between October 2020 and March 2021 (eg measures adopted by The Cypriot Government); postponement of tax and social security payments for the tourism sector until the resumption of activities (quarter III estimate of the year), sectors that were severely affected by the pandemic (eg tourism, restaurants, entertainment, sports, cultural services, transport) will be exempted from paying social security contributions, payroll taxes and small business tax. The employees' contribution will be reduced until the resumption of the activity (respectively quarter III of the year); and cultural support: emergency support funding for the most affected artists and entities ( $€ 1$ million); Resolution mechanism for the protection of canceled cultural and artistic performances (Manta, 0. 2020).

In a healthy and rational society, strategy and action are not subordinated to ideology, doctrine. The action must be based on the rules governing each case. There is something quite satisfying about expressing a political and economic belief such as: "I am absolutely on the side of the free initiative" (Galbraith K.J., 1997).

Our future research on European funding instruments, funding models and funding programs is based on references to current decisions at European level, all the more so as the seven-year programming period is very clearly regulated by EU directives and regulations. European Commission.

\section{Bibliography}

[1] Boumans, D, S. Link and S. Sauer. (2020). COVID-19: The World Economy Needs a Lifeline - But Which One? European Network of Economic and Fiscal Policy Research, IFO Institute. 
[2] Galbraith K.J., (1997), The Perfect Society, Eurosong\&Book Publishing, Romania;

[3] Dorn et al. 2020. 'The Economic Costs of the Coronavirus Shutdown for Selected European Countries: A Scenario Calculation'. Econpol Policy Brief 25.

[4] European Commission. (2020). Temporary Framework for State aid measures to support the economy in the current COVID-19 outbreak. Available at: https://ec.europa.eu/competition/state_aid/what_is_new/sa_covid19_temp oraryframework.pdf.

[5] Manta, Otilia. (2017). The New Challenges in Economic Science. Germany: LAP Lambert Academic Publishing.

[6] Manta, Otilia. (2020). "Nothing for us without us", Measures applied at European level during the current crisis. Journal For Freedom of Conscience.

[7] S. López Piqueres, Does COVID-19 pose a threat to the EU's climate neutrality efforts?, EPC Commentary, 31 March 2020.

[8] R. Waldholz, (2020), EU should use Green Deal as road map for coronavirus stimulus - foundations, Clean Energy Wire (CLEW);

[9] R. Waldholz, EU should use Green Deal as road map for coronavirus stimulus - foundations, Clean Energy Wire (CLEW), 19 March 2020.

[10] https://europa.eu/

[11] European Commission, Sustainable Europe Investment Plan: European Green Deal Investment Plan, COM(2020) 21, 14 January 2020. 